\title{
How Many Citations to Women is "Enough"? \\ Estimates of Gender Representation in Political Science ${ }^{1}$ \\ Michelle L. Dion \\ Sara McLaughlin Mitchell
}

\begin{abstract}
Recent studies have identified gendered citation gaps in political science journal articles, with male scholars being less likely to cite work by female scholars in comparison to their female peers. While journal editors, editorial boards, and political scientists are becoming more aware of implicit biases and adopting strategies to remedy them, we know less about the proper baselines for citations in subfields and research areas of political science. Without information about how many women should be cited in a research field, it is difficult to know whether the distribution is biased. Using the gender distribution of membership in professional political science organizations and of article authors in 38 political science journals, we provide scholars with baselines for gender representation in citations. We also show that women represent a larger share of organization members than the authors in sponsoring organizations' journals.
\end{abstract}

Keywords: political science, sociology of science, gender

Michelle L. Dion is an associate professor in the Department of Political Science at McMaster University. She can be reached at dionm@mcmaster.ca.

Sara McLaughlin Mitchell is F. Wendell Miller Professor of Political Science at University of Iowa. She can be reached at sara-mitchell@uiowa.edu.

Final accepted version for PS: Political Science and Politics, June 2019. 


\title{
How Many Citations to Women is "Enough"? \\ Estimates of Gender Representation in Political Science
}

Michelle L. Dion

\section{Sara McLaughlin Mitchell}

\begin{abstract}
"I don't want to read all this stuff, so would appreciate if someone could answer this question for me: for those who argue too few women are cited, what is the normative standard for the amount women should be cited? Is there some proportion they say is right, or is the standard more nuanced than that?" - Natille's [anonymous] response to "Gender bias in citations" thread on poliscijobrumors.com (Natille [anonymous] 2018).
\end{abstract}

Recent political science studies have identified gendered citation gaps in journal articles (Dion, Sumner and Mitchell 2018; Maliniak, Powers, and Walter 2013; Mitchell, Lange, and Brus 2013), with male scholars being less likely than their female peers to cite work by female scholars. These findings may explain the underrepresentation of female authors in syllabi (Colgan, 2017; Hardt et al 2017), edited volumes (Matthews and Andersen 2001), and textbooks (Cassesse et al 2012). While many in the discipline are becoming more aware of implicit biases and adopting strategies to remedy them, many political scientists, including the anonymous author of the quote that opens this article responding to an online discussion about evidence of gendered biases in citations (Dion, Sumner, and Mitchell 2018), want to how many citations to work by women is "enough." This is particularly important if journals begin adopting policies to promote gender balance in citations (e.g., International Studies Review 2018), and we recognize that some research areas within political science are more gender balanced than others. For 
example, if an article on international security has $40 \%$ of its citations to female authors, is the author sufficiently recognizing research contributions by women? While $40 \%$ of citations to women might be reasonable in international security, $40 \%$ of citations to women in an article on gender and politics would be biased, given much greater women's representation in that area. Without information about women's representation in a specific research area, it is difficult to know whether the distribution of cited authors is biased, even when calculating the gender and racial breakdown of references (e.g., Sumner 2018).

Our study provides political scientists with estimates of women's representation across a wide range of research fields using the gender distribution in professional association membership and authors in 38 political science journals. While other studies have discussed gender across APSA member sections (Reid and Curry 2019) or authors in a much smaller subset of journals (Dion, Sumner, and Mitchell 2018; Teele and Thelen 2017), we also compare the gender distribution of authors to those of journal sponsor organizations, illustrating the size of the gendered publication gap across a large number of research fields within political science. In only one of 26 journals for which we also have membership data from the sponsoring section or organization did the journal publish significantly more female authors than its membership. In all other cases, women were equally or underrepresented among journal authors, suggesting that membership may be a more useful baseline for publication and citation rates of work by female scholars. We argue that scholars should consider gender representation in their research areas if they want to minimize implicit biases in their citation practices. 


\section{Background Literature}

Professional associations and the National Science Foundation (NSF) collect demographic information (including gender) about awarded degrees and scholars in political science. Mitchell and Hesli (2013) use NSF data to show declining percentages of women in the discipline as ranks increase, noting that women constitute $40 \%$ of doctoral degrees in the field, but only $28 \%$ of APSA members in 2009; a decade later it was still only 33.6\% of members (APSA 2018). These data accord with other estimates of women's participation in professional associations (Breuning and Sanders 2007). Similarly, Teele and Thelen (2017) note that women make up 27\% of faculty in the largest $20 \mathrm{PhD}$ granting departments, $31 \%$ of APSA members, and $40 \%$ of $\mathrm{PhDs}$ in political science. Hancock, Baum and Breuning (2013: 6) report that among ISA members, $20 \%$ of women are full professors, compared with $34 \%$ of men. These types of aggregate disciplinary snapshots identify the population of female scholars in our profession, but they do not identify nuanced differences across disciplinary subfields or narrow substantive areas of interest, which often have significant variations in gender distributions.

A second approach for determining how many female scholars work in a research area involves coding the sex of journal article or book authors in a discipline (Evans and Moulder 2011; Williams et al 2015). Breuning and Sanders (2007) find that women were only $21 \%$ of article authors in eight political science journals (1999-2004), even though their representation in APSA and ISA then exceeded 30\%. Østby et al (2013) find that women authored or coauthored $23 \%$ of 947 articles in the Journal of Peace Research between 1983 and 2008. Teele and Thelen (2017) note that around $35 \%$ of articles are authored or coauthored by women in ten political science journals from 2000-2015 ( $>$ > 8,000 articles). Like aggregate membership data, these snapshots of eight to ten political science journals are usually weighted toward general journals 
that publish research from all subfields of political science, rather than narrower research topics which may significantly deviate from aggregate, discipline-wide distributions.

Comparisons of organizational membership and published authors also reveals potential gendered publication gaps if women's representation as article authors is significantly less than their presence in a field. Breuning and Sanders (2007) find that women are much less represented in ISA journals than in ISA sections, while Teele and Thelen (2017) show that most political science journals fail to publish a percentage of female authors similar to their APSA representation (31\%). Several processes could produce publication gaps, including: 1) the leaky pipeline, or fewer women at senior ranks; 2) lower article submission rates of women compared to men (Djupe, Smith, and Sokhey 2019; Hesli and Lee 2011); 3) the rise of co-authorship, which benefits primarily male authors (Teele and Thelen 2017); and 4) gender biases in editorial decision-making processes. A recent special section in PS: Political Science \& Politics suggests that there are no significant gender biases in editors' decisions for five journals (Brown and Samuels 2018), but the persistent gendered publication gap points to more pernicious sources, like leaky pipelines and gendered co-authorship or submission rates. For example, Djupe, Smith, and Sokhey (2019, figs. 2-3) find that men overall have authored more peer-reviewed articles than women (Hesli and Lee 2011), but this difference is driven by significant differences between men and women at associate professor rank. Nonetheless, existing studies fail to provide insights into variations in publication gaps across topical research areas, which are also indicative of potential biases in pipelines, co-authorship, or submission rates. 


\section{How Many Citations to Women is “Enough"?}

The previous section suggests that we can think about gender balance in our bibliographies, textbooks, syllabi, and speaker invitations by examining the representation of women in professional organizations and their sections. The citation literature shows, though, that there are implicit biases in citation decision-making. Men's research can be viewed as more central or important in a field ("Matthew" effect), while women's work can be ignored or worse, attributed to men in a field ("Matilda" effect) (Rossiter 1993). Even in fields like women in politics where female scholars are a majority of all authors, male authors in Politics \& Gender are still 14\% less likely than female authors to cite the work of women (Dion, Sumner and Mitchell 2018). While recruitment and retention of more women can reduce citation gaps, we must raise awareness of implicit biases in citation decisions. Put differently, gendered publication or citation gaps between membership and authorship in related academic journals provide insights into research areas where potential biases in pipelines, co-authorship, or submission rates remain significantly large. In this regard, our data provide more nuanced information about relevant gendered baselines for scholars who wonder whether they are missing research by women in their articles, books, and syllabi as well as those who want to identify research areas in which gendered biases in publication and citations may be most significant.

\section{Gender Distribution of Faculty by Field and Organized Sections in APSA}

We use APSA field and section membership to establish minimum baselines for the proportion of references that should include female authors, similar to Reid and Curry's (2019) use of membership data to estimate progress toward descriptive representation across political science research areas. If publications are an outcome potentially influenced by gendered practices, 
professional association memberships may be less biased baselines because membership involves fewer resources and gatekeepers. Nevertheless, membership figures can be genderbiased to the extent that women are more concentrated in non-R1 institutions with lower levels of research support or less likely to have research funding. ${ }^{2}$ In 2018, of APSA members with self-reported genders, $35.8 \%$ identified as female, $64.1 \%$ as male, and $0.1 \%$ as other genders (see Table 1). If research productivity and publication processes are gender neutral, then journals that publish work in all research areas, such as American Political Science Review or Perspectives on Politics, should have one third of article authors and bibliography entries be female. Of course, if women submit to journals at lower rates than men (Djupe, Smith, and Sokhey 2019) and if men cite research by other men at higher rates (Dion, Sumner, and Mitchell 2018), then these selection effects may result in gendered publication and citation gaps.

Membership in more specialized organizations, like APSA's organized sections or affiliated groups (e.g., Society for Political Methodology) represent a wide range of research areas and the smallest relevant research communities for our analysis. Indeed, female APSA members join organized sections at a significantly higher rate than male APSA members; $68.3 \%$ of women belong to at least one section, while $64.1 \%$ of men do (Table 1, column 2: $\chi^{2}=$ 18.277, $\mathrm{p}=0.000$ ). Female APSA members also belong to a significantly higher average number of sections than men (Table 1, column 3: ANOVA, F $=21.73, \mathrm{p}=0.000$ ). This is consistent with women in political science being more oriented towards community building (Mitchell and Hesli 2013) as well as women having less specialized research trajectories and more interdisciplinary research (Leahey 2006, 2007). 
Table 2 presents the proportion of APSA members who self-identify as female by: a) self-identified primary field of study, b) membership in organized sections, and c) in APSA overall. We exclude those with no gender identity provided but include those who identified as other genders. In 2018, significantly more women identified their primary research or teaching field as public policy (41.4\%) or comparative politics (39.3\%) than the overall female representation in APSA (35.8\%) in 2018. ${ }^{3}$ In contrast, women are significantly underrepresented among members who claim political philosophy and theory (31.6\% female) or political methodology (19.4\% female). Other large fields, including international politics, American politics, public administration, and public law/courts, have similar (e.g. not significantly lower) female representation rates to overall APSA levels.

Organized section membership provides an even more detailed breakdown than primary field of research areas because organized sections organize research panels at annual meetings, sponsor specialized research conferences or journals, and recognize research contributions with professional awards. The data are broadly consistent with prior research, which has noted, for example, that women are more likely to study human rights (Maliniak, Powers, and Walter 2013) and less likely to study methodology (Dion, Sumner, and Mitchell 2018; Shames and Wise 2017). Several research areas have female membership that significantly exceeds overall representation in APSA, and in these areas (e.g. Race, Ethnicity, and Politics), a representative bibliography would cite more than $35.8 \%$ of works written by women. In a handful of areas (e.g. legislative studies), women are significantly less represented than in APSA overall, and a representative bibliography might have fewer works by women than female membership in APSA. When political scientists compose course syllabi, graduate reading lists, or research 
bibliographies, these membership data provide some guidance about the minimum representation of scholarship by women that should be included to be representative by gender.

\section{Gender Distribution of Authors by Journal}

Using a methodology similar to previous studies (Dion, Sumner, and Mitchell 2018; Sumner 2018; Teele and Thelen 2017), we code the gender of the first five authors for a large sample of 38 political science journals, including all articles published between 2007 and 2016 by journals sponsored by APSA organized sections and those of regional and international political science associations. ${ }^{4}$ Figure 1 plots the female proportion of authors (with $95 \%$ confidence intervals) in this sample alongside the female proportion of the journal's sponsoring APSA section or organization membership in 2017 or 2018 , when available. ${ }^{5}$ The proportion of all authors who are likely female vary from a high of 0.829 female authors in Politics \& Gender to a low of 0.141 female authors in Political Analysis. Similar to the findings of Teele and Thelen (2017), who found that women were underrepresented in high impact journals compared to the profession, this figure illustrates the gap between recent membership and authorship across a much larger number of research areas. In at least 13 journals, female authors are significantly underrepresented compared to their membership in the sponsoring organization, and in no instances are women "over" represented among authors, suggesting underlying gendered practices as play. Indeed, these gendered publication gaps are often greatest in the highest status journals that publish all subfields and research areas of political science (e.g., APSR, AJPS, or $J O P)$. These data cannot tell us why women are less represented as authors than as organization members across such a wide range of general and narrow research areas. As explained earlier, women might be less likely to submit their work or more likely to exit the discipline or 
experience bias during the publication process. Therefore, as a measure of the supply of female authors available to be cited, the proportion of authors that are female is a conservative estimate.

Previous research has also considered article author team composition ( Dion, Sumner, and Mitchell 2018; Teele and Thelen 2017), recognizing homophily effects in collaborations and that collaboration is more common in some research areas. Therefore, we also coded the first five authors of each article published in our sample as solo female, solo male, female team, male team, or mixed gender team (see Appendix). ${ }^{6}$ Only in Politics \& Gender and Journal of Race, Ethnicity, and Politics do the percentage of solo female authored articles exceed that of solo male authored articles and the percentage of female team authored articles exceed that of male team authored articles. Both of these areas have high rates of female participation in the journal's sponsoring organization. If we consider journals in which the modal author team is collaborative (not solo), the modal collaborative team is either all male or mixed gender, never all female. Four journals (Journal of Race, Ethnicity, and Politics, Journal of Experimental Political Science, Public Opinion Quarterly, and Political Communication) have more mixed gender author teams than other types of author configurations. Five journals (AJPS, PA, JCR, BJPS, and $J O P$ ) have mostly male only collaborative author teams. This reflects tendencies both for women to engage in fewer collaborative publications and to work in fields (like comparative politics) where collaboration is less common.

\section{Conclusion and Recommendations}

Recent studies document gender gaps in citations in political science, yet we lack benchmarks for how many female-authored works are enough for a representative bibliography across a wide range of research areas. We remedy this gap by explicitly providing estimates of gender diversity 
based on organization membership and journal article authorship that are conservative estimates for evaluating gender representation. Instructors, researchers, and editors who want to ensure references are representative can reference these as floors (rather than ceilings) for minimally representative citations. However, our study does not evaluate scholars' decisions to join professional association sections or examine whether variance in gender representation among sections reflects personal preferences, perceived section biases, or both. Our dataset simply provides a benchmark, while recognizing that these unobserved factors influence scholarly engagement with APSA and other associations.

Political scientists should reflect upon their own citation practices to ensure that their references are consistent with gendered distribution of research in their area. Likewise, journal editors can explicitly ask peer reviewers to consider whether article bibliographies are representative, including the distribution of author genders. Some journals have gone further, explicitly evaluating the gender balance of article bibliographies and encouraging authors to remedy gendered citation gaps by providing additional space to do so (International Studies Review 2018). APSA sections that sponsor journals should evaluate whether the publications provide ample descriptive representation of section members. In addition, those that select journal editorial teams should pay attention not only to the diversity of the editorial team, but also their plans for addressing potential citation biases. Luckily, tools like the GBAT (Sumner 2018) help political scientists quickly and easily evaluate gender balance in their bibliographies. Over time, as the discipline becomes more gender balanced across research areas, these estimates will need to be updated and adjusted. Finally, while we have focused here on gender diversity (and particularly cis-gender identities), future research and recommendations should 
consider racial or ethnic diversity as well as intersectional identities to ensure that research by underrepresented groups is referenced adequately in political science teaching and research. 


\section{References}

Abu-Laban, Yasmeen, Marian Sawer, and Mathieu St-Laurent. 2017. IPSA Gender and Diversity Monitoring Report 2017, Montreal, QC: International Political Science Association, July, 36.

APSA. 2018. APSA Membership Dashboard. Washington, D.C.: American Political Science Association. February 28, 2018 update. https://www.apsanet.org/RESOURCES/Data-onthe-Profession/Dashboard/Membership/Organized-Sections.

Brown, Nadia E., and David Samuels. 2018. "Introduction to Gender in the Journals, Continued: Evidence from Five Political Science Journals.” PS: Political Science \& Politics 51 (4): $847-48$.

Bruening Marijke, and Kathryn Sanders. 2007. "Gender and Journal Authorship in Eight Prestigious Political Science Journals.” PS: Political Science and Politics 40(2): 347-51.

Cassese, Erin C., Angela L. Bos, and Lauren E. Duncan. 2012. "Integrating Gender into the Political Science Core Curriculum.” PS: Political Science \& Politics 45 (2): 238-43.

Colgan, Jeff. 2017. “Gender Bias in International Relations Graduate Education? New Evidence from Syllabi.” PS: Political Science \& Politics 50 (2): 456-60.

Clucas, Richard. 2018. "WPSA Membership \& Gender,” October 11, 2018. Personal correspondence.

Dion, Michelle L., Jane Lawrence Sumner, and Sara McLaughlin Mitchell. 2018. “Gendered Citation Patterns across Political Science and Social Science Methodology Fields.” Political Analysis 26 (3): 312-27 
Djupe, Paul A., Amy Erica Smith, and Anand Edward Sokhey. 2019. "Explaining Gender in the Journals: How Submission Practices Affect Publication Patterns in Political Science.” PS: Political Science \& Politics 52 (1): 71-77.

Evans, Heather K., and A. Moulder. 2011. 'Reflecting on a Decade of Women's Publications in Four Top Political Science Journals.” PS: Political Science \& Politics 44 (4): 793-798.

Hancock, Kathleen J., Matthew A. Baum, and Marijke Breuning. 2013. "Women and Pre-Tenure Scholarly Productivity in International Studies: An Investigation into the Leaky Career Pipeline.” International Studies Perspectives 14 (4): 507-27.

Hardt, Heidi, Hannah Kim, Philippe Meister, and Amy E. Smith. 2017. "Diversity by the Book: Gender Representation in Political Science Graduate Training." Paper presented at the Annual Convention of the Midwest Political Science Association, Chicago, IL.

Hesli Vicki L., and Jae Mook Lee. 2011. "Faculty Research Productivity: Why Do Some of Our Colleagues Publish More than Others?" PS: Political Science and Politics 44(2): 393408.

Howard, Robert M. 2018. "SPSA Membership \& Gender,” October 12, 2018. Personal correspondence.

International Studies Review. 2018. "Facebook Post.” Facebook. July 31, 2018. https://www.facebook.com/permalink.php?story_fbid $=1785439848176494 \& \mathrm{id}=5828467$ 98435811.

Maliniak, Daniel, Ryan Powers, and Barbara F. Walter. 2013. "The Gender Citation Gap in International Relations.” International Organization 67 (4): 889-922. 
Mathews, A. Lanethea and Kristi Andersen. 2001. “A Gender Gap in Publishing? Women’s Representation in Edited Political Science Books." PS: Political Science and Politics 34(1): 143-147.

Morgan, William. 2018. “MPSA Membership \& Gender,” October 11, 2018 Personal correspondence.

Mitchell, Sara McLaughlin, and Vicki L. Hesli. 2013. “Women Don’t Ask? Women Don’t Say No? Bargaining and Service in the Political Science Profession." PS: Political Science \& Politics 46 (2): 355-69.

Mitchell, Sara McLaughlin, Samantha Lange, and Holly Brus. 2013. "Gendered Citation Patterns in International Relations Journals.” International Studies Perspectives 14 (4): 485-92.

Natille [anonymous]. 2018. "Gender Bias in Citations'." poliscijobrumors.com. https://www.poliscirumors.com/topic/gender-bias-in-citations\#post-1163396.

Østby, Gudrun, Håvard Strand, Ragnhild Nordås, and Nils Petter Gleditsch. 2013. “Gender Gap or Gender Bias in Peace Research? Publication Patterns and Citation Rates for Journal of Peace Research, 1983-2008.” International Studies Perspectives 14 (4): 493-506.

Reid, Rebecca A., and Todd A. Curry. 2019. "Are We There Yet? Addressing Diversity in Political Science Subfields.” PS: Political Science \& Politics, 52 (2): 281-86/

Roberts, Margaret E, Brandon M. Stewart and Richard Nielsen. 2016. "Matching Methods for High-Dimensional Data with Applications to Text." Working paper available at http://www.margaretroberts.net/.

Rossiter, Margaret W. 1993. “The Matthew Matilda Effect in Science.” Social Studies of Science 23 (2): $325-41$. 
Shames, Shauna L., and Tess Wise. 2017. "Gender, Diversity, and Methods in Political Science: A Theory of Selection and Survival Biases.” PS: Political Science \& Politics 50 (3): $811-23$.

Sumner, Jane Lawrence. 2018. “The Gender Balance Assessment Tool (GBAT): A Web-Based Tool for Estimating Gender Balance in Syllabi and Bibliographies.” PS: Political Science \& Politics, 51 (2): 396-400.

Teele, Dawn Langan, and Kathleen Thelen. 2017. "Gender in the Journals: Publication Patterns in Political Science." PS: Political Science \& Politics 50 (2): 433-47.

Williams, Helen, Stephen Bates, Laura Jenkins, Darcy Luke, and Kelly Rogers. 2015. “Gender and Journal Authorship: An Assessment of Articles Published by Women in Three Top British Political Science and International Relations Journals." European Political Science 14:116-30. 
Table 1: Mean number of section memberships by gender (2018)

\begin{tabular}{|c|c|c|c|c|c|c|c|c|}
\hline \multirow[b]{3}{*}{$\begin{array}{l}\text { Gender } \\
\text { identity }\end{array}$} & \multicolumn{3}{|c|}{ (1) } & \multicolumn{3}{|c|}{ (2) } & \multicolumn{2}{|c|}{ (3) } \\
\hline & \multicolumn{3}{|c|}{ APSA Members } & \multicolumn{3}{|c|}{$\begin{array}{l}\text { Members w/section } \\
\text { membership(s) }\end{array}$} & \multicolumn{2}{|c|}{$\begin{array}{l}\text { Sections } \\
\text { /member }\end{array}$} \\
\hline & $\mathrm{N}$ & $\begin{array}{l}\% \text { of } \\
\text { total }\end{array}$ & $\begin{array}{l}\% \text { of } \\
\text { valid }\end{array}$ & $\mathrm{N}$ & $\begin{array}{c}\% \text { of } \\
\text { gender }\end{array}$ & $\begin{array}{l}\% \text { of } \\
\text { valid }\end{array}$ & Mean & Std dev. \\
\hline Female & 3565 & $33.6 \%$ & $35.8 \%$ & 2436 & $68.3 \%$ & $37.3 \%$ & 1.88 & 2.26 \\
\hline Male & 6376 & $60.2 \%$ & $64.1 \%$ & 4086 & $64.1 \%$ & $62.6 \%$ & 1.67 & 2.07 \\
\hline Other & 7 & $0.1 \%$ & $0.1 \%$ & 5 & $71.4 \%$ & $0.1 \%$ & 2.43 & 1.81 \\
\hline No answer & 650 & $6.1 \%$ & & 184 & $28.3 \%$ & & 0.57 & 1.20 \\
\hline Total & 10598 & $100.0 \%$ & $100.0 \%$ & 6711 & & $100.0 \%$ & 1.67 & 2.11 \\
\hline
\end{tabular}

Source: Authors' calculations based on APSA (2018). 
Table 2: Proportion female members of APSA by section and primary field (2018)

\begin{tabular}{|c|c|c|c|c|c|c|}
\hline Field/Section & Female & Male & Other & $\begin{array}{c}\text { No } \\
\text { answer }\end{array}$ & $\begin{array}{c}\text { Mem- } \\
\text { bers }\end{array}$ & $\begin{array}{c}\text { Prop. } \\
\text { Female }\end{array}$ \\
\hline 16. Women \& Politics & 388 & 36 & 0 & 16 & 440 & 0.92 \\
\hline 36. Human Rights & 202 & 155 & 1 & 10 & 368 & 0.56 \\
\hline 43. Migration \& Citizenship & 179 & 140 & 0 & 10 & 329 & 0.56 \\
\hline 39. Health Politics \& Policy & 117 & 110 & 0 & 4 & 231 & 0.52 \\
\hline 38. Sexuality \& Politics & 78 & 74 & 2 & 3 & 157 & 0.51 \\
\hline 33. Race, Ethnicity \& Politics & 279 & 283 & 0 & 10 & 572 & 0.50 \\
\hline 44. African Politics Conference & 127 & 137 & 0 & 39 & 303 & 0.48 \\
\hline 29. Political Science Education & 144 & 177 & 0 & 5 & 326 & 0.45 \\
\hline 37. Qual \& Multi-Method Rs. & 308 & 390 & 1 & 17 & 716 & 0.44 \\
\hline 04. Public Policy & 246 & 330 & 0 & 16 & 592 & 0.43 \\
\hline 20. Comparative Politics & 490 & 666 & 3 & 24 & 1183 & 0.42 \\
\hline 15. Sci., Tech. \& Env. Pol. & 140 & 192 & 0 & 4 & 336 & 0.42 \\
\hline 45. Class \& Inequality & 102 & 141 & 0 & 3 & 246 & 0.42 \\
\hline Field: Public Policy & 239 & 338 & 0 & 8 & 585 & 0.41 \\
\hline 27. New Political Science & 121 & 177 & 1 & 6 & 305 & 0.40 \\
\hline 06. Public Administration & 118 & 179 & 0 & 8 & 305 & 0.40 \\
\hline 35. Comparative Democratization & 217 & 328 & 3 & 11 & 559 & 0.40 \\
\hline Field: Comparative Politics & 1091 & 1683 & 2 & 49 & 2825 & 0.39 \\
\hline 18. Info. Tech. \& Politics & 64 & 99 & 0 & 3 & 166 & 0.39 \\
\hline 07. Conflict Processes & 173 & 271 & 0 & 5 & 449 & 0.39 \\
\hline 21. European Politics \& Society & 124 & 199 & 1 & 3 & 327 & 0.38 \\
\hline 23. Political Communication & 166 & 269 & 0 & 5 & 440 & 0.38 \\
\hline 13. Urban \& Local Politics & 99 & 162 & 0 & 4 & 265 & 0.38 \\
\hline 42. Experimental Research & 157 & 263 & 1 & 10 & 431 & 0.37 \\
\hline 41. Political Networks & 145 & 245 & 0 & 10 & 400 & 0.37 \\
\hline 28. Political Psychology & 178 & 306 & 0 & 1 & 485 & 0.37 \\
\hline 30. Politics, Literature, \& Film & 114 & 196 & 0 & 8 & 318 & 0.37 \\
\hline 17. Foundations of Pol. Th. & 226 & 401 & 0 & 15 & 642 & 0.36 \\
\hline Field: International Politics & 772 & 1375 & 3 & 39 & 2189 & 0.36 \\
\hline APSA members & 3565 & 6376 & 7 & 650 & 10598 & 0.36 \\
\hline 46. Ideas, Knowledge \& Politics & 93 & 171 & 0 & 5 & 269 & 0.35 \\
\hline Field: American Politics & 751 & 1397 & $\mathbf{0}$ & 20 & 2168 & 0.35 \\
\hline 11. Religion \& Politics & 135 & 254 & 0 & 17 & 406 & 0.35 \\
\hline Field: Public Administration & 81 & 154 & $\mathbf{0}$ & 5 & 240 & 0.34 \\
\hline 02. Law \& Courts & 145 & 280 & 0 & 0 & 425 & 0.34 \\
\hline 08. Rep. \& Electoral Systems & 100 & 200 & 0 & 4 & 304 & 0.33 \\
\hline 24. Politics \& History & 161 & 326 & 0 & 7 & 494 & 0.33 \\
\hline 22. State Politics \& Policy & 106 & 225 & 0 & 5 & 336 & 0.32 \\
\hline
\end{tabular}




\begin{tabular}{lcccccc}
\hline Field: Public Law \& Courts & $\mathbf{1 1 7}$ & $\mathbf{2 4 8}$ & $\mathbf{1}$ & $\mathbf{7}$ & $\mathbf{3 7 3}$ & $\mathbf{0 . 3 2}$ \\
\hline Field: Political Philosophy \& Theory & $\mathbf{4 0 9}$ & $\mathbf{8 8 5}$ & $\mathbf{0}$ & $\mathbf{2 7}$ & $\mathbf{1 3 2 1}$ & $\mathbf{0 . 3 2}$ \\
\hline 25. Political Economy & 179 & 396 & 1 & 12 & 588 & 0.31 \\
34. International History \& Politics & 105 & 236 & 0 & 13 & 354 & 0.31 \\
01. Fed'm \& Intergovernmental Rel. & 58 & 132 & 0 & 2 & 192 & 0.31 \\
31. Foreign Policy & 118 & 269 & 1 & 8 & 396 & 0.30 \\
19. International Security & 120 & 283 & 0 & 11 & 414 & 0.30 \\
40. Canadian Politics & 51 & 124 & 0 & 5 & 180 & 0.29 \\
32. Elections, Pub. Op, \& Voting & 184 & 454 & 0 & 4 & 642 & 0.29 \\
05. Political Orgs. \& Parties & 92 & 242 & 0 & 5 & 339 & 0.28 \\
09. Presidents \& Executive Politics & 87 & 248 & 0 & 8 & 343 & 0.26 \\
03. Legislative Studies & 98 & 304 & 0 & 5 & 407 & 0.24 \\
47. American Political Thought & 42 & 144 & 0 & 4 & 190 & 0.23 \\
10. Political Methodology & 124 & 440 & 2 & 8 & 574 & 0.22 \\
\hline Field: Methodology & $\mathbf{3 8}$ & $\mathbf{1 5 7}$ & $\mathbf{1}$ & $\mathbf{5}$ & $\mathbf{2 0 1}$ & $\mathbf{0 . 1 9}$ \\
\hline
\end{tabular}

Source: Authors' calculations based on APSA (2018). Proportions of members with declared gender (excluding "no answers"), sorted in descending order by proportion female. 
Figure 1: Proportion female authors of journals and the membership of sponsoring section or association, with $95 \%$ confidence intervals

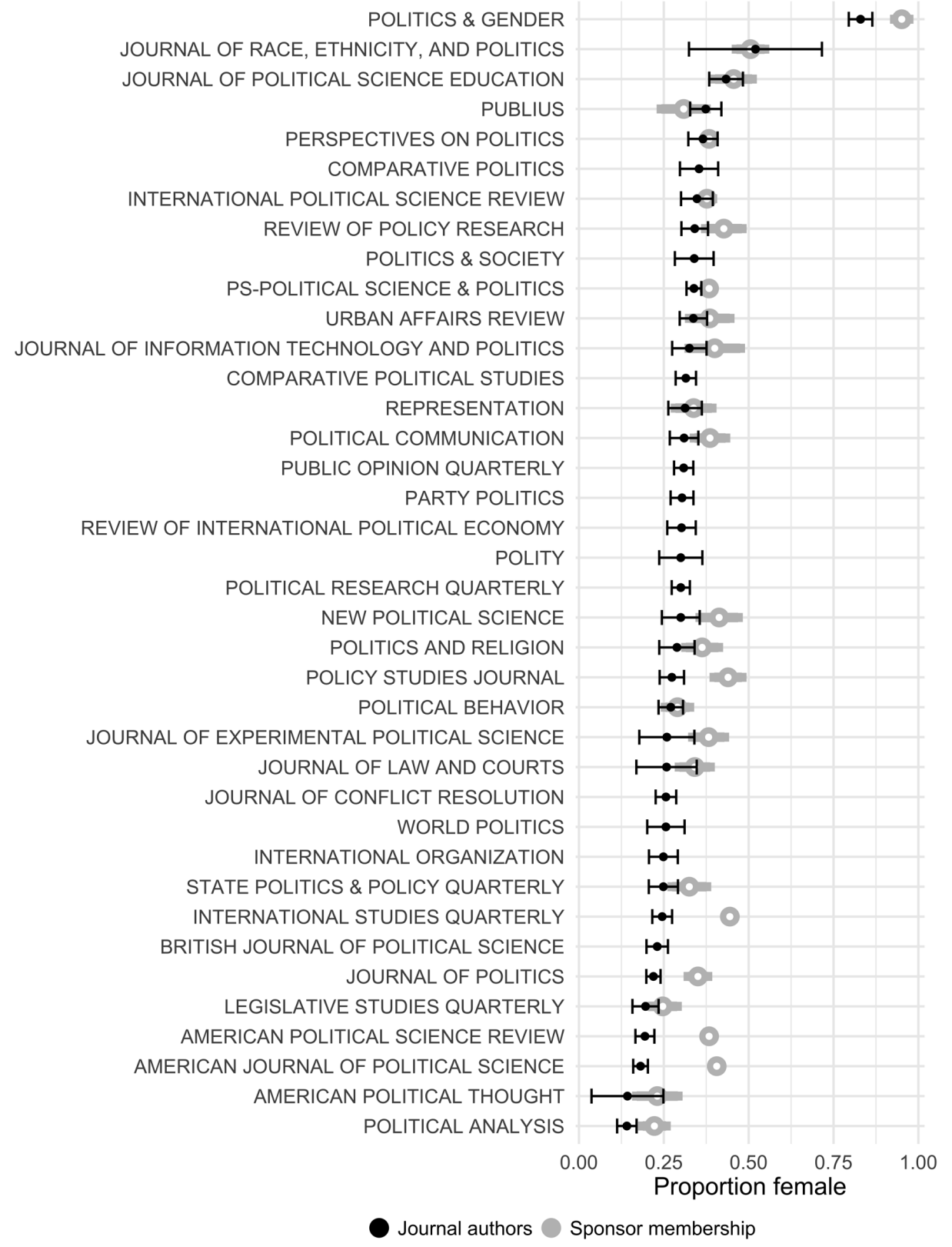

Note: APSA and Organized Section membership as of 2018 (APSA 2018), other organization membership as of 2017 (see fn. 7), and journal authors for 2007-2016 for available years. APSA membership used for APSA flagship journals: APSR and Perspectives on Politics. Point estimates with 95\% confidence intervals. See Appendix for complete list of journal publication years included in sample. 
Notes

${ }^{1}$ We are grateful to Yanna Krupnikov for comments on an earlier version of this project.

${ }^{2}$ In the 2004 National Study of Postsecondary Faculty $(\mathrm{N}=26,100)$, women constituted 42.5\% of all respondents but only $36.5 \%$ of public doctoral and $34.6 \%$ of private doctoral degree granting institutions, showing that women are less represented in R1 institutions (National Center for Education Statistics 2019). This suggests that the data we analyze may underestimate women's representation in the discipline if such institutions provide fewer resources on average for joining professional associations.

${ }^{3}$ Here we consider differences significant if the $95 \%$ confidence interval for the female proportion of a field's members does not include the overall proportion of female APSA members.

${ }^{4}$ We used the Genderize.io API, which generates a predicted probability that a first name is used by someone who identifies as male or female based on millions of social media profiles. We code names as male or female if the predicted probability is equal to or greater than 0.8 . Teele and Thelen (2017) found that Genderize.io has a 2\% error rate. Years vary because some journals were founded since 2007; see Appendix for years included in sample by journal. ${ }^{5}$ The overall female proportion of APSA is plotted for its three flagship journals, APSR, Perspectives on Politics, and PS: Political Science and Politics. Membership data as of 2017 for the International Political Science Association (sponsor of IPSR) from Abu-Laban, Sawer, and St-Laurent (2017), for the Midwest Political Science Association (sponsor of AJPS) from Morgan (2018), for the Southern Political Science Association (sponsor of JOP) from Howard (2018). The Western Political Science Association (sponsor of $P R Q$ ) does not track members' 
genders. Membership information was also requested from the leadership of the Northeastern Political Science Association (sponsor of Polity), International Studies Association (sponsor of $I S Q$ ), the American Association for Public Opinion Research (sponsor of $P O Q$ ), and Peace Science Society (sponsor of $J C R$ ).

${ }^{6}$ Articles with at least one male and one female author are coded as mixed, even if authors' genders are incomplete. Male and female only require that all authors' genders be coded. Missing cases occur when some gender authors are missing and coded authors are all the same gender. 


\section{How Many Citations to Women is "Enough"? Estimates of Gender Representation in Political Science Michelle L. Dion and Sara McLaughlin Mitchell Supplemental Appendix}

\section{Recommended citation:}

Michelle L. Dion and Sara McLaughlin Mitchell. 2019. "Gendered Citation Patterns across Political Science and Social Science Methodology Fields.” PS: Political Science \& Politics. Supplemental Appendix, 1-5.

\section{Journal sample statistics}

\begin{tabular}{|c|c|c|c|c|c|c|}
\hline Journal name & $\begin{array}{c}\text { First } \\
\text { year in } \\
\text { sample }\end{array}$ & $\begin{array}{l}\mathrm{N} \text { of } \\
\text { Authors }\end{array}$ & $\mathrm{N}$ coded & $\begin{array}{l}\text { Propor- } \\
\text { tion } \\
\text { coded }\end{array}$ & $\begin{array}{l}\text { Female } \\
\text { authors }\end{array}$ & $\begin{array}{c}\text { Female } \\
\text { propor- } \\
\text { tion }\end{array}$ \\
\hline AJPS & 2007 & 1289 & 1218 & 0.94 & 221 & 0.18 \\
\hline APSR & 2007 & 827 & 772 & 0.93 & 150 & 0.19 \\
\hline AMERICAN POLITICAL THOUGHT & 2015 & 44 & 42 & 0.95 & 6 & 0.14 \\
\hline BJPS & 2007 & 729 & 681 & 0.93 & 157 & 0.23 \\
\hline CPS & 2007 & 999 & 921 & 0.92 & 290 & 0.31 \\
\hline $\mathrm{CP}$ & 2007 & 318 & 277 & 0.87 & 98 & 0.35 \\
\hline IO & 2007 & 431 & 398 & 0.92 & 99 & 0.25 \\
\hline IPSR & 2007 & 457 & 397 & 0.87 & 138 & 0.35 \\
\hline ISQ & 2007 & 910 & 836 & 0.92 & 205 & 0.25 \\
\hline JCR & 2007 & 874 & 800 & 0.92 & 205 & 0.26 \\
\hline J OF EXPERIMENTAL POLI SCI & 2014 & 123 & 112 & 0.91 & 29 & 0.26 \\
\hline J OF INFO TECH AND POLITICS & 2007 & 378 & 329 & 0.87 & 107 & 0.33 \\
\hline J OF LAW AND COURTS & 2013 & 96 & 93 & 0.97 & 24 & 0.26 \\
\hline J OF POLI SCI EDUCATION & 2007 & 421 & 383 & 0.91 & 166 & 0.43 \\
\hline JOP & 2007 & 1576 & 1495 & 0.95 & 328 & 0.22 \\
\hline J OF RACE, ETHNICITY, AND POLITICS & 2016 & 30 & 25 & 0.83 & 13 & 0.52 \\
\hline LSQ & 2007 & 427 & 408 & 0.96 & 80 & 0.20 \\
\hline NEW POLITICAL SCIENCE & 2007 & 282 & 260 & 0.92 & 78 & 0.30 \\
\hline PARTY POLITICS & 2007 & 774 & 718 & 0.93 & 218 & 0.30 \\
\hline PERSPECTIVES ON POLITICS & 2008 & 508 & 479 & 0.94 & 175 & 0.37 \\
\hline POLICY STUDIES JOURNAL & 2007 & 658 & 592 & 0.90 & 162 & 0.27 \\
\hline POLITICAL ANALYSIS & 2007 & 611 & 567 & 0.93 & 80 & 0.14 \\
\hline POLITICAL BEHAVIOR & 2007 & 622 & 584 & 0.94 & 158 & 0.27 \\
\hline POLITICAL COMMUNICATION & 2007 & 513 & 465 & 0.91 & 144 & 0.31 \\
\hline PRQ & 2007 & 1211 & 1130 & 0.93 & 339 & 0.30 \\
\hline POLITICS \& GENDER & 2008 & 489 & 452 & 0.92 & 375 & 0.83 \\
\hline POLITICS \& SOCIETY & 2007 & 292 & 265 & 0.91 & 90 & 0.34 \\
\hline POLITICS AND RELIGION & 2008 & 330 & 291 & 0.88 & 84 & 0.29 \\
\hline POLITY & 2007 & 218 & 200 & 0.92 & 60 & 0.30 \\
\hline PS-POLITICAL SCIENCE \& POLITICS & 2007 & 1920 & 1795 & 0.93 & 608 & 0.34 \\
\hline PUBLIC OPINION QUARTERLY & 2007 & 1082 & 1021 & 0.94 & 315 & 0.31 \\
\hline PUBLIUS & 2007 & 470 & 423 & 0.90 & 158 & 0.37 \\
\hline REPRESENTATION & 2007 & 374 & 339 & 0.91 & 106 & 0.31 \\
\hline RIPE & 2007 & 512 & 460 & 0.90 & 139 & 0.30 \\
\hline REVIEW OF POLICY RESEARCH & 2007 & 653 & 563 & 0.86 & 192 & 0.34 \\
\hline SPPQ & 2007 & 412 & 390 & 0.95 & 97 & 0.25 \\
\hline URBAN AFFAIRS REVIEW & 2007 & 593 & 528 & 0.89 & 178 & 0.34 \\
\hline WORLD POLITICS & 2007 & 262 & 242 & 0.92 & 62 & 0.26 \\
\hline
\end{tabular}

Authors' coding of authors' probable gender using genderize.io API with jsonlite ver. 1.5 (Ooms, Lang, and Hilaiel 2017) in R (ver. 3.3.2). Source data from Web of Science or ProQuest. 


\begin{tabular}{|c|c|c|c|c|c|c|}
\hline & $\begin{array}{c}\text { Female } \\
\text { team }\end{array}$ & $\begin{array}{l}\text { Male } \\
\text { team }\end{array}$ & $\begin{array}{c}\text { Mixed } \\
\text { gender } \\
\text { team }\end{array}$ & $\begin{array}{c}\text { Solo } \\
\text { female }\end{array}$ & $\begin{array}{l}\text { Solo } \\
\text { male }\end{array}$ & $\mathrm{N}$ coded \\
\hline AMERICAN JOURNAL OF POLITICAL SCIENCE & $2.4 \%$ & $40.7 \%$ & $22.7 \%$ & $7.7 \%$ & $26.4 \%$ & 572 \\
\hline AMERICAN POLITICAL SCIENCE REVIEW & $2.9 \%$ & $32.8 \%$ & $15.8 \%$ & $11.2 \%$ & $37.3 \%$ & 418 \\
\hline AMERICAN POLITICAL THOUGHT & $0.0 \%$ & $0.0 \%$ & $0.0 \%$ & $14.3 \%$ & $85.7 \%$ & 42 \\
\hline BRITISH JOURNAL OF POLITICAL SCIENCE & $3.2 \%$ & $33.0 \%$ & $26.3 \%$ & $8.6 \%$ & $28.9 \%$ & 339 \\
\hline COMPARATIVE POLITICAL STUDIES & $4.2 \%$ & $24.6 \%$ & $23.2 \%$ & $17.5 \%$ & $30.5 \%$ & 521 \\
\hline COMPARATIVE POLITICS & $3.7 \%$ & $13.9 \%$ & $14.4 \%$ & $25.7 \%$ & $42.2 \%$ & 187 \\
\hline INTERNATIONAL ORGANIZATION & $1.3 \%$ & $24.0 \%$ & $23.1 \%$ & $15.3 \%$ & $36.2 \%$ & 229 \\
\hline INTERNATIONAL POLITICAL SCIENCE REVIEW & $6.5 \%$ & $13.8 \%$ & $17.8 \%$ & $17.0 \%$ & $44.9 \%$ & 247 \\
\hline INTERNATIONAL STUDIES QUARTERLY & $4.0 \%$ & $25.6 \%$ & $19.1 \%$ & $10.8 \%$ & $40.5 \%$ & 481 \\
\hline JOURNAL OF CONFLICT RESOLUTION & $2.8 \%$ & $33.3 \%$ & $28.2 \%$ & $11.3 \%$ & $24.4 \%$ & 390 \\
\hline JOURNAL OF EXPERIMENTAL POLITICAL SCIENCE & $2.4 \%$ & $31.0 \%$ & $40.5 \%$ & $11.9 \%$ & $14.3 \%$ & 42 \\
\hline JOURNAL OF INFORMATION TECHNOLOGY AND POLITICS & $5.0 \%$ & $17.0 \%$ & $34.0 \%$ & $11.9 \%$ & $32.1 \%$ & 159 \\
\hline JOURNAL OF LAW AND COURTS & $3.8 \%$ & $25.0 \%$ & $19.2 \%$ & $13.5 \%$ & $38.5 \%$ & 52 \\
\hline JOURNAL OF POLITICAL SCIENCE EDUCATION & $11.2 \%$ & $13.0 \%$ & $22.8 \%$ & $20.0 \%$ & $33.0 \%$ & 215 \\
\hline JOURNAL OF POLITICS & $3.0 \%$ & $32.8 \%$ & $23.7 \%$ & $8.9 \%$ & $31.6 \%$ & 756 \\
\hline JOURNAL OF RACE, ETHNICITY, AND POLITICS & $11.1 \%$ & $0.0 \%$ & $77.8 \%$ & $11.1 \%$ & $0.0 \%$ & 9 \\
\hline LEGISLATIVE STUDIES QUARTERLY & $1.8 \%$ & $34.4 \%$ & $18.3 \%$ & $10.1 \%$ & $35.3 \%$ & 218 \\
\hline NEW POLITICAL SCIENCE & $2.0 \%$ & $8.0 \%$ & $7.5 \%$ & $24.5 \%$ & $58.0 \%$ & 200 \\
\hline PARTY POLITICS & $3.6 \%$ & $24.4 \%$ & $19.8 \%$ & $19.1 \%$ & $33.1 \%$ & 414 \\
\hline PERSPECTIVES ON POLITICS & $3.7 \%$ & $16.4 \%$ & $12.3 \%$ & $28.7 \%$ & $38.9 \%$ & 324 \\
\hline POLICY STUDIES JOURNAL & $5.5 \%$ & $26.7 \%$ & $25.0 \%$ & $12.0 \%$ & $30.8 \%$ & 292 \\
\hline POLITICAL ANALYSIS & $1.2 \%$ & $40.8 \%$ & $23.8 \%$ & $1.9 \%$ & $32.3 \%$ & 260 \\
\hline POLITICAL BEHAVIOR & $4.2 \%$ & $26.8 \%$ & $25.8 \%$ & $11.1 \%$ & $32.1 \%$ & 287 \\
\hline POLITICAL COMMUNICATION & $4.1 \%$ & $22.9 \%$ & $33.9 \%$ & $11.5 \%$ & $27.5 \%$ & 218 \\
\hline POLITICAL RESEARCH QUARTERLY & $6.3 \%$ & $26.0 \%$ & $22.4 \%$ & $12.9 \%$ & $32.4 \%$ & 599 \\
\hline POLITICS \& GENDER & $16.0 \%$ & $1.3 \%$ & $12.7 \%$ & $63.8 \%$ & $6.2 \%$ & 307 \\
\hline POLITICS \& SOCIETY & $3.9 \%$ & $15.6 \%$ & $13.9 \%$ & $24.4 \%$ & $42.2 \%$ & 180 \\
\hline POLITICS AND RELIGION & $3.3 \%$ & $17.7 \%$ & $15.5 \%$ & $19.3 \%$ & $44.2 \%$ & 181 \\
\hline
\end{tabular}




\section{POLITY}

PS-POLITICAL SCIENCE \& POLITICS

PUBLIC OPINION QUARTERLY

PUBLIUS

REPRESENTATION

REVIEW OF INTERNATIONAL POLITICAL ECONOMY

REVIEW OF POLICY RESEARCH

STATE POLITICS \& POLICY QUARTERLY

URBAN AFFAIRS REVIEW

WORLD POLITICS

NOTE: Journal author teams for 2007-2016 for available years.

$\begin{array}{cccccc}1.2 \% & 5.3 \% & 5.3 \% & 26.3 \% & 62.0 \% & 171 \\ 5.2 \% & 16.4 \% & 18.5 \% & 19.4 \% & 40.5 \% & 1074 \\ 4.9 \% & 25.5 \% & 40.3 \% & 6.3 \% & 23.0 \% & 427 \\ 10.2 \% & 16.1 \% & 25.4 \% & 12.7 \% & 35.6 \% & 236 \\ 4.5 \% & 11.4 \% & 9.8 \% & 19.6 \% & 54.7 \% & 245 \\ 2.5 \% & 13.2 \% & 13.2 \% & 20.7 \% & 50.5 \% & 319 \\ 4.6 \% & 13.3 \% & 19.4 \% & 17.7 \% & 44.9 \% & 345 \\ 2.6 \% & 29.5 \% & 26.4 \% & 10.4 \% & 31.1 \% & 193 \\ 3.8 \% & 18.2 \% & 32.6 \% & 15.2 \% & 30.3 \% & 264 \\ 2.0 \% & 23.0 \% & 16.4 \% & 18.4 \% & 40.1 \% & 152\end{array}$




\section{Estimating Women's Representation with APSA Survey Data}

In addition to estimating the distribution of women in research fields using APSA section membership, we can also calculate gender representation using two recent APSA membership surveys. The first wave of the APSA survey included a sample of 1,399 APSA members from the population of 5,179 APSA members, stratified by department size and surveyed in early fall 2009 (Mitchell and Hesli 2013; Hesli, Lee, and Mitchell 2012; Hesli and Lee 2011). The second wave drew a new 1,051 APSA member sample from the 2009 population file, and respondents answered surveys during late fall 2014 and early winter 2015 (Claypool et al. 2017). The proportion of women answering the survey increased from $24.9 \%$ of respondents in 2009 to $39.2 \%$ in 2014-15. ${ }^{1}$ Figure A1 illustrates the gender distribution of APSA members in the surveys overall and according to members' major field of PhD study and primary field of research and teaching in 2009 and in 2014. Major PhD field has a fixed list of responses, including American Politics, Comparative Politics, International Relations, Theory, Methods, and Other. The surveys also use an open-ended question to ask about a respondent's primary research and teaching field, which is re-coded to mirror the PhD major field response options (e.g., general political science, political behavior, political economy were recoded to "other").

Across the major and primary fields, women's representation increased between the two waves. In 2014-15, among respondents who identified Comparative Politics, Political Theory, or other fields as the major field in their PhD program, more than $40 \%$ are female respondents. Among respondents who identified American Politics or International Relations as their major field, 36.5\% and 32.1\% are female. In both waves of the survey, only three respondents reported Methods as their major PhD field, and one of these identified as female in the first wave, none in the second. When asked their primary field of teaching and research, more than $40 \%$ of respondents in American and Comparative Politics identified as female in 2014-15. In contrast, women are only $34.8 \%$ and $38.3 \%$ of those working primarily in IR or Political Theory, respectively. Of the 16 respondents who identify Methods as their primary teaching and research field in 2014-15, only one is female (6.3\%). While the proportion of female APSA survey respondents vary by major and primary fields, the $95 \%$ confidence intervals for all major and primary fields except Methods overlap with the overall proportion of women in the survey (39.2\%).

\section{PhD major field \& primary teaching/research field in APSA surveys}
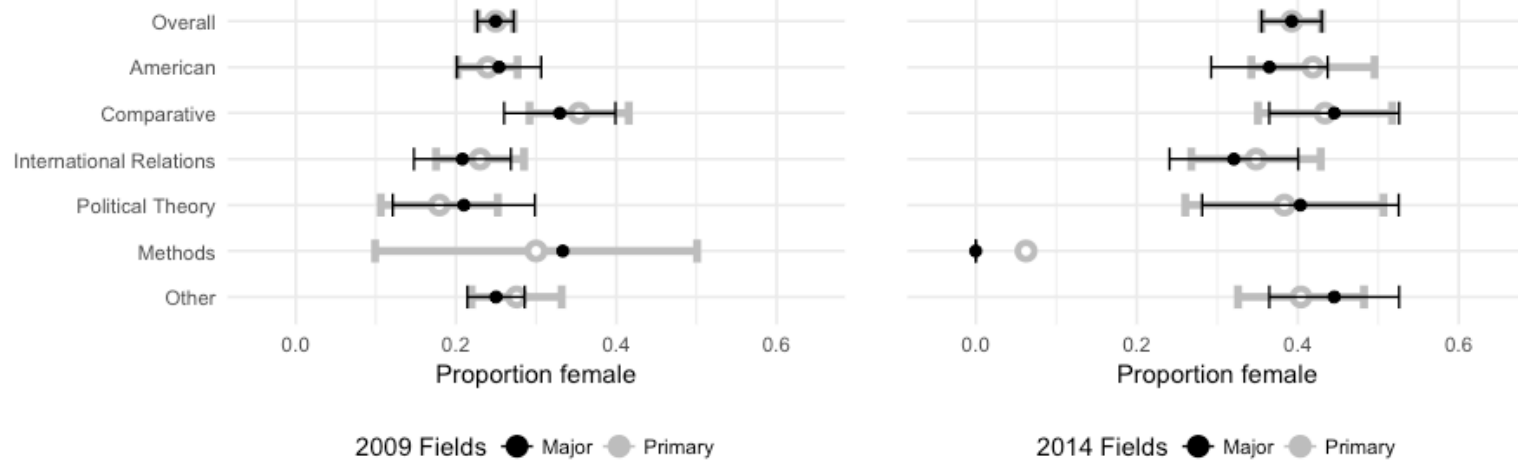

Authors' elaboration based on Claypool et al (2017) and Hesli, Lee, and Mitchell (2012).

Source:

\footnotetext{
${ }^{1}$ Gender responses included male, female, and transgender, but only a handful of survey respondents selected transgender, thus we compare males and females in our analyses.
} 


\section{References}

Claypool, Vicki Hesli, Brian David Janssen, Dongkyu Kim, and Sara McLaughlin Mitchell. 2017. "Determinants of Salary Dispersion among Political Science Faculty: The Differential Effects of Where You Work (Institutional Characteristics) and What You Do (Negotiate and Publish)." PS: Political Science \& Politics 50 (1): 146-56.

Hesli Vicki L., and Lee Jae Mook. 2011. "Faculty Research Productivity: Why Do Some of Our Colleagues Publish More than Others?" PS: Political Science and Politics 44(2): 393-408.

Hesli, Vicki L., Jae Mook Lee, and Sara McLaughlin Mitchell. 2012. "Predicting Rank Attainment in Political Science: What Else Besides Publications Affects Promotion?" PS: Political Science \& Politics 45 (03): 475-92.

Mitchell, Sara McLaughlin, and Vicki L. Hesli. 2013. "Women Don't Ask? Women Don't Say No? Bargaining and Service in the Political Science Profession." PS: Political Science \& Politics 46 (2): 355-69.

Ooms, Jeroen, Duncan Temple Lang, and Lloyd Hilaiel. 2017. Jsonlite: A Robust, High Performance JSON Parser and Generator for R (version 1.5). https://cran.rproject.org/web/packages/jsonlite/index.html. 